\title{
Nodular and epicellular coccidiosis in the intestine of cyprinid fishes
}

\author{
Kálmán Molnár \\ Veterinary Medical Research Institute, Hungarian Academy of Sciences, PO Box 18, H-1581 Budapest, Hungary
}

\begin{abstract}
In the intestine of $10(\mathrm{n}=18)$ cyprinid fish species collected from natural waters of Hungary, the author demonstrated oocysts which were shed unsporulated. In tapwater, oocysts sporulated within 24 to $48 \mathrm{~h}$. In 6 of the fish species, oocysts of 2 sizes were observed. Histological examinations proved that, of the morphologically similar oocysts, larger ones developed in nodules in size of a pinhead in certain segments of the gut. Smaller oocysts were formed in the epicellular layer of epithelial cells and were distributed evently in the intestine. Both nodular and epicellular type coccidioses are characterized by a 1-yr developmental cycle. Infection is demonstrable only in the spring. Merogonic stages were found in March and gamogonic stages in April. By May, the infection practically disappeared. Oocysts collected from different fish species varied slightly in morphology. Therefore, without knowing host specificity, only the nodular and epicellular coccidia found in the most intensively infected fish species, Blicca bjoerkna, are described as new species, Goussia balatonica and Goussia pannonica.
\end{abstract}

\section{INTRODUCTION}

Until quite recently, limited information was available on fish coccidia. However, the number of coccidian species demonstrated in f:shes has increased considerably in the last few years and several have been described outside Europe e.g. from America (Upton et al. 1984), Africa (Obikezie 1986) and Australia (Molnár \& Rohde 1988a). New species of coccidia have also. been described from marine fishes (Lom \& Dykova 1982, Daoudi et al. 1987, Molnár \& Rohde 1988b).

Oocysts of the majority of species described undergo sporulation within their hosts - however, data on species in which unsporulated oocysts are released are scarce (Leger \& Bory 1932, Hoffman 1965, Molnár \& Rohde 1988a). The majority of oocidian gut species are located diffusely in the intestinal epithelium. Only Goussia subepithelialis and a Goussia sp. described from tench (Molnár 1982) are known to develop in nodules in a circumscribed area of the epithelium. For a long time, G. subepithelialis was regarded as a species developing in the subepithelium (Schäperclaus 1943, Pellérdy \& Molnár 1968). However, Marincek (1973) proved that this parasite developed in the gut epithelium. Furthermore, Molnár (1984) has demonstrated that oocysts of this parasite are driven into the subepithelium by a secondary host reaction. Eimeria anguillae (Leger \& Hollande 1922) and Goussia pigra (Leger \& Bory 1932) are the best known fish coccidians which develop in an epicellular location. However, Molnár (1986), Landsberg \& Paperna (1987), Jastrzebski et al. (1988), Kent et al. (1988), and Molnár \& Rohde (1988a) have recently reported additional epicellular coccidia.

The aim of this paper is to demonstrate that cyprinid species are frequently infected by relatively wellknown parasites which cause diffuse coccidiosis and also by less known nodular or epicellular coccidia. The latter two leave the fish unsporulated and their oocysts appear in the early spring months as a result of a yearly developmental cycle. Of the oocysts very similar in morphology and location, those collected from the white bream (Blicca bjoerkna) have been described as new species: Goussia balatonica and $G$. pannonica.

\section{MATERIALS AND METHODS}

These studies were conducted between April 1986 and June 1988. In 1986, coccidian infection was surveyed throughout the year. In 1987 and 1988, systematic studies were performed only in the spring months. However, samples were occasionally taken at other times of the year. Over a 3-yr period, a total of 249 fish 


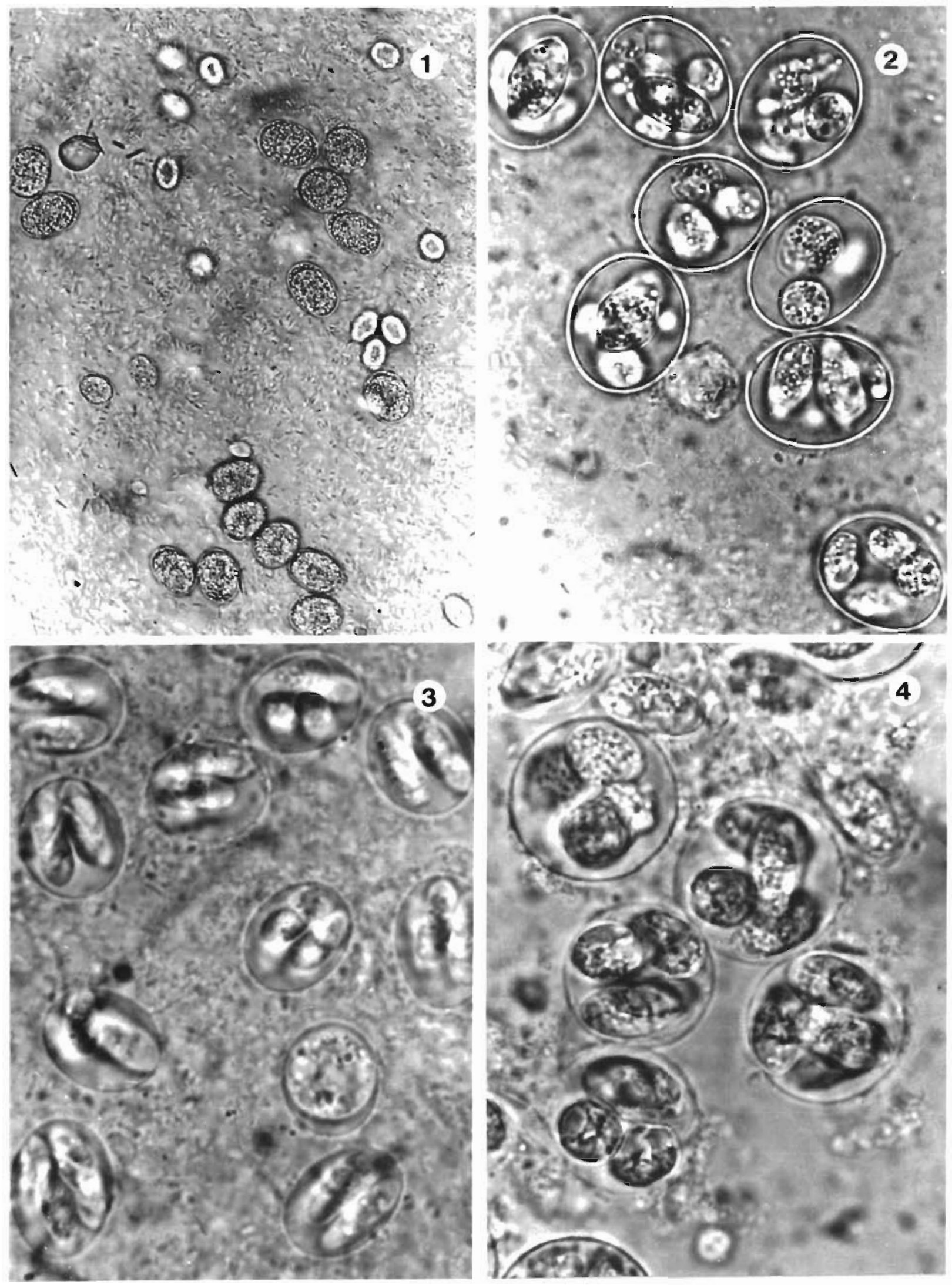


belonging to 18 cyprinid species were examined for the presence of nodular occidiosis. The majority of fishes examined came from Lake Balaton and the River Danube, Hungary, although a smaller number were taken from the creeks Tápió and Kemence (tributaries of Rivers Tisza and Ipoly, respectively). Fish were caught with a seine ne: and transported alive to the laboratory where they were processed within 4 to $6 \mathrm{~d}$. Fish kept in the laboratory without feeding for at least $2 \mathrm{~d}$ and whose intestinal contents had been excreted, proved the most suitable for reliable diagnosis of coccidial infection. The gut of these fish was slit open longitudinally and examined under a microscope. The mucus and scrapings taken from different segments of the gut were studied with a light microscope. Oocysts were easiest to demonstrate in the glassy mucus lining the gut, but could also be found in the intestinal scrapings. In positive and doubtful cases, smaller pieces of unaffected intestinal segments or of nodules seen on the intestinal wall were fixed in $10 \%$ buffered formalin or Bouin's solution. In some cases the whole gut was wound up and fixed in its entirety. Samples were embedded in paraffin, 3 to $4 \mu \mathrm{m}$ thick sections cut and stained with haematoxylin and eosin ( $\mathrm{H} \& \mathrm{E})$. Unsporulated oocysts found in nodules from the gut wall and in mucus were placed in Petri dishes or on a watch-glass and allowed to sporulate in tap water changed several times for 24 to $48 \mathrm{~h}$. To prevent bacterial growth, a loopful of penicillin or streptomycin was added to the water.

Dimensions of the new species of Goussia were determined from measurements of 50 oocysts and are given as mean followed by range ( $\mu \mathrm{m})$.

\section{RESULTS}

\section{Prevalence}

In early April 1986, nodules containing gamogonic stages of a Goussia sp. were found in the gut of a bleak Alburnus alburnus caught in Lake Balaton. Further studies consistently revealed the presence of nodules containing similar unsporulated oocysts in the gut of other fish species, primarily white bream Blicca bjoerkna. In mucus taken from the gut of white bream, 2 types of unsporulated oocysts (Fig. 1) were demonstrable in high numbers: a larger $(17-19 \times 12-13 \mu \mathrm{m})$ oocyst and a smaller one $(12.5-13.6 \times 8.3-9.2 \mu \mathrm{m})$. In tap water, oocysts sporulated within $48 \mathrm{~h}$ and increased slightly in size. Oocysts scraped from nodules always represented the larger species (Fig. 2). Later, histological examination revealed that the coccidium having smaller oocysts represented a Goussia sp. which developed in large numbers in an epicellular location on the surface of the intestinal epithelium (Fig. 3), Infection was demonstrable exclusively in the early spring and disappeared almost completely by the end of April. From May onward, occasional examination of the fish revealed only the presence of the species causing so-called carpelli-type diffuse coccidiosis (G. carpelli, G. cyprinorum)

Oocysts shed unsporulated, developing in nodules or in the epicellular location, were found in the gut of 10 fish species (Table 1). In 6 cyprinids both the nodular and epicellular types occurred; in 2 species, only the nodular type was found, while in another 2 the site of oocyst development could not be precisely located. In all fish species, infection typically occurred in the early spring. At that time (of fish species examined in sufficient numbers) infection was most prevalent in Blicca bjoerkna ( $75 \%$ ), and ca $50 \%$ in Abramis brama and Rutilus rutilus. The earliest infection was demonstrated in fish caught in March, immediately after the ice had thawed. At that time, merogonic stages were still present in species of Blicca, Alburnus and Leuciscus and gamogonic stages had already appeared. The intensity of infection was highest in April. By mid-April oocysts had been formed in nodules and were expelled into the intestinal lumen unsporulated. The development of species with smaller oocysts in an epicellular location took place about 2 wk later. The merogonic stages of this species were demonstrable at the beginning of April and oocyst shedding was completed by the end of the month. In the majority of cases, infection was highly intensive. No appreciable difference was noted between fish caught in Lake Balaton and in the Danube, in terms of the prevalence and intensity of infection.

Despite the high intensity of coccidial infection, there was no evidence of pathogenicity. Fish transported to the laboratory intact survived the observation period without showing signs of disease. Dying fish did not weigh less nor were they more severely infected than apparently healthy fish.

Despite intensive infection occasionally involving as much as $70 \%$ of the intestine, there was no evidence of necrosis of gut epithelium, nor were inflammatory cells observed. The pathologic effect was limited to the destruction of infected epithelial cells. Mucus released

Figs. 1 to 4. Goussia spp. Fic. 1. Unsporulated G. balatonica (larger) and G. pannonica (smaller) oocysts in the intestinal mucus; $(x$ 500). Fig. 2. G. balatonica. Oocysts after $24 \mathrm{~h}$ sporulation; ( $\times 1300)$. Fig. 3. G. pannonica. Oocysts after 48 h sporulation; ( $\times 1300)$. Fig. 4. G. subepithelialis. Oocysts after 24 h sporulation; $(\times 1300)$ 


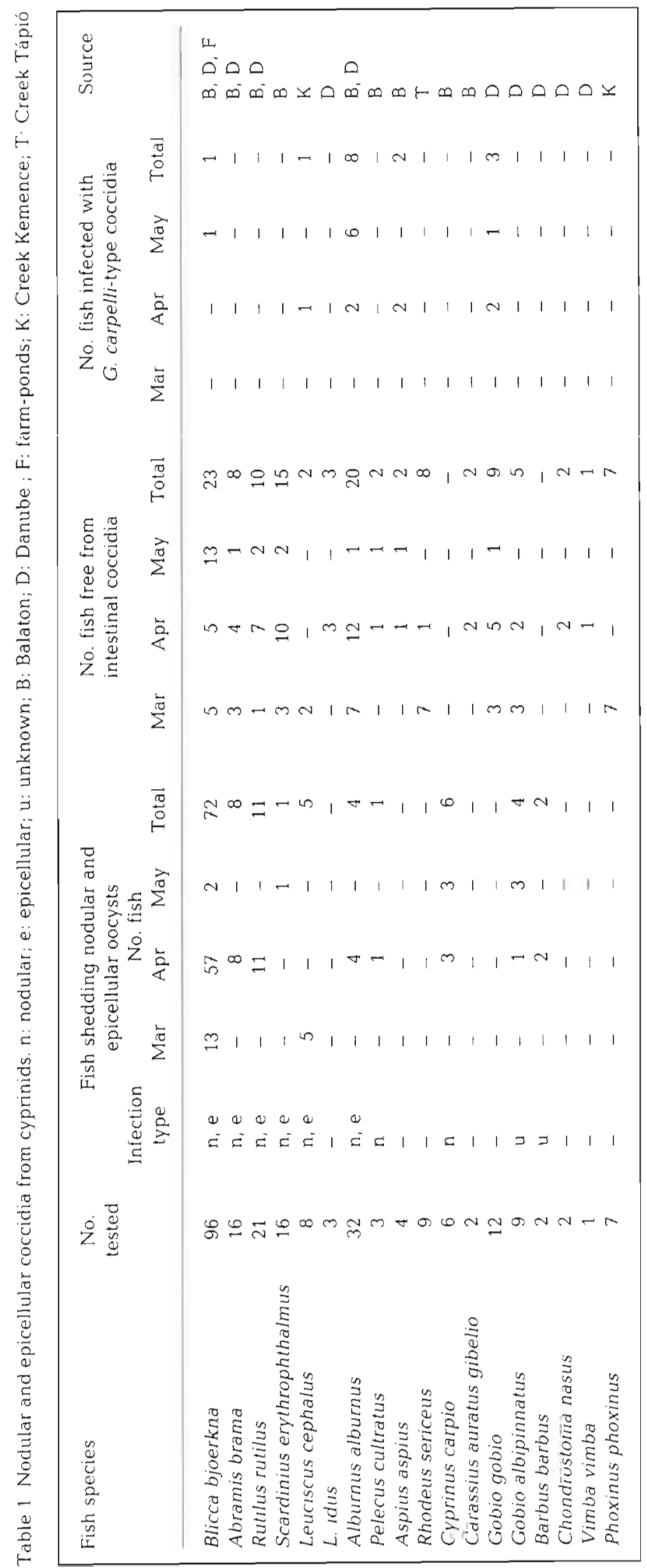




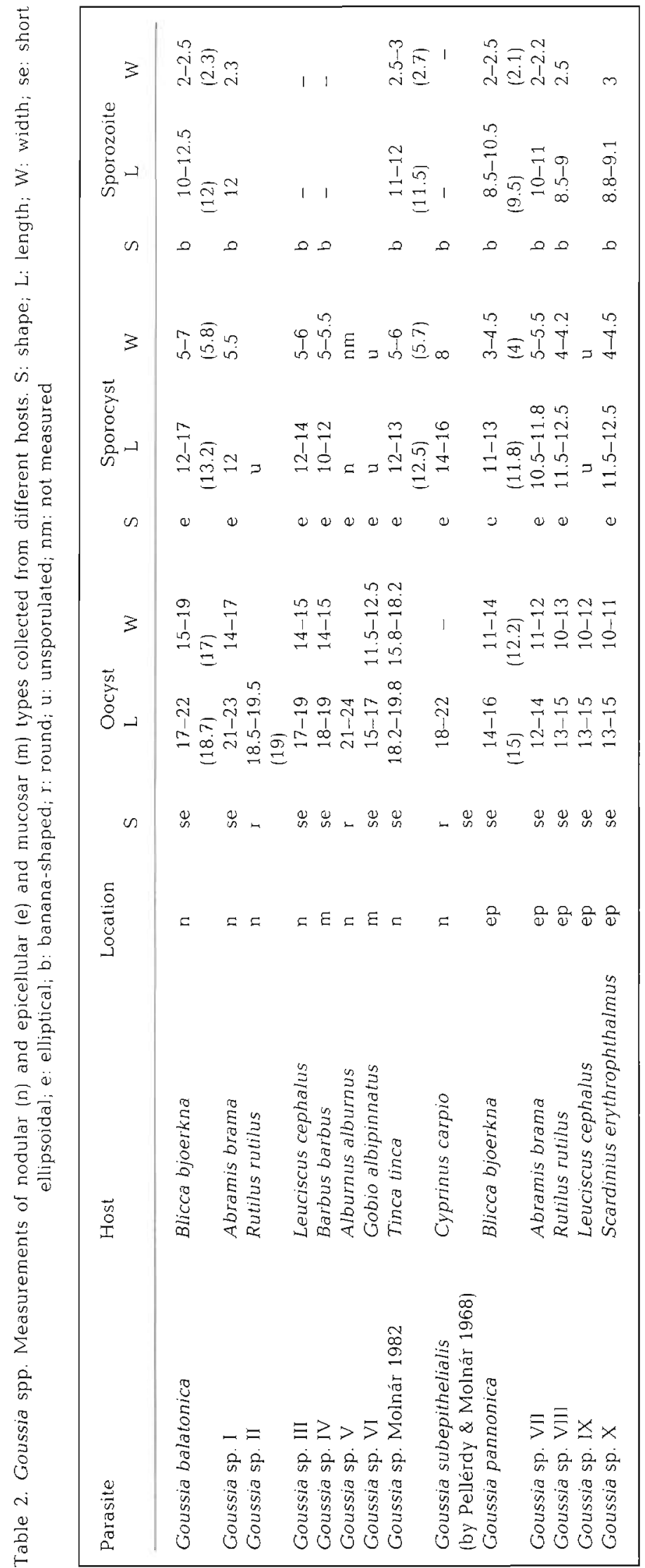




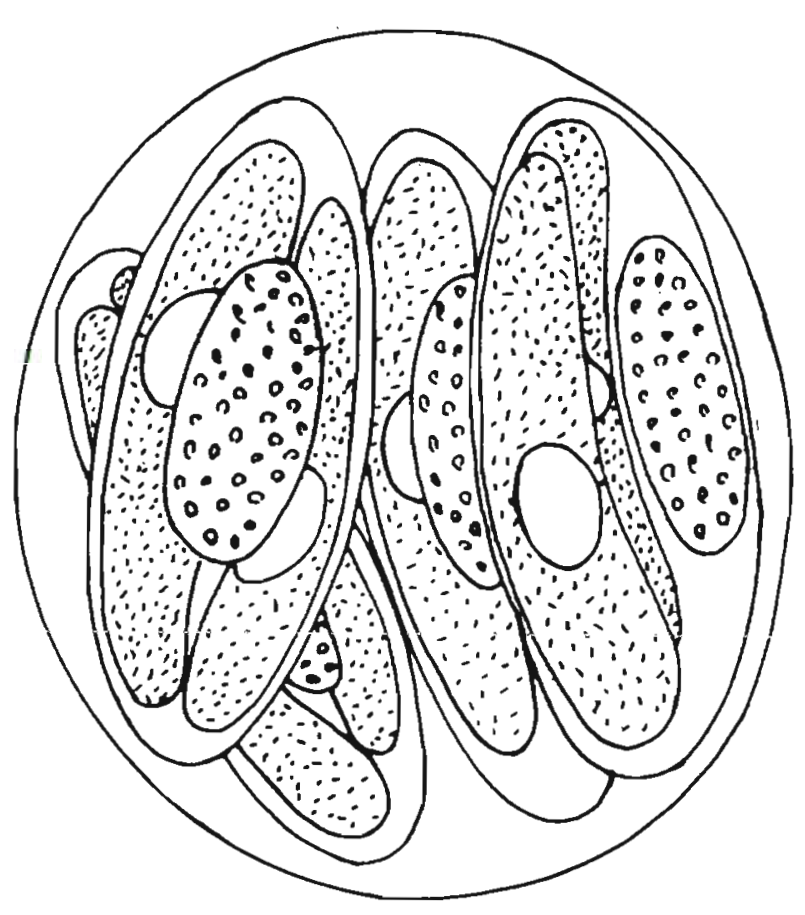

$10 \mu \mathrm{m}$

Fig. 5. Goussia balatonica. Oocyst

from them covered the gut in a tubelike fashion and contained masses of oocysts.

Both modular and epicellular coccidiosis were demonstrable in the fish species examined. In some cases, coccidia, both nodular and epicellular in location, occurred in a given segment of the gut (Fig. 6). Morphological differences between oocysts released from nodules and those shed from the surface of the intestinal epithelium within a given fish species were negligible. Differences in size were, however, significant.

No distinct morphological differences were demonstrable between nodular and epicellular oocysts derived from various cyprinid fishes. There were, however, smaller differences in size (Table 2). The size of the fish had no influence on that of the oocyst.

Oocysts derived from nodules represented the larger type typical of Goussia subepithelialis, G. pigra, G. molnari and G. schulmani. Smaller oocysts differed from the former in size. As, of coccidia demonstrated in this study, only those found in common carp were identified as $G$. subepithelialis (Fig. 4), and since it cannot be decided whether the species found in the other hosts represent 1 or more species, only the 2 most prevalent and most intensively studied coccidia parasitizing Blicca bjoerkna are described as the new species G. balatonica and G. pannonica.

\section{Species descriptions}

Goussia balatonica n. sp. is found in the white bream Blicca bjoerkna, of Lake Balaton and the River Danube, where it forms nodules 1 to 1,5 mm diam. in the mucosa of the intestine.

Short ellipsoidal oocysts (Fig. 5), $18.7(17-22) \mu \mathrm{m}$ long and $17(15-19) \mu \mathrm{m}$ wide have a thin, smooth and colourless wall and lack oocyst residuum, polar granules and micropyle.

The unsporulated oocysts that leave the fish are (Fig. 1) compact, elliptical and measure $17.9 \times 12.9$ $(17-19 \times 12-13) \mu \mathrm{m}$. Oocysts kept in tap water at $22{ }^{\circ} \mathrm{C}$ completed sporulation within $48 \mathrm{~h}$. Merogonic and gamogonic stages were studied histologically.

Sporocysts are elongated ellipsoids, $13.2(12-17)$ $\mu \mathrm{m}$ long and $5.8(5-7) \mu \mathrm{m}$ wide, and are generally arranged longitudinally in oocysts. The sporocyst wall is thin and composed of 2 equal valves joined by a suture. Each sporocyst contains 2 bananashaped sporozoites which possess large refractile nuclei. Sporozoites are $12(10-12.5) \mu \mathrm{m}$ long and $2.3(2-2.5) \mu \mathrm{m}$ wide. Their residuum is finely granulated and fills the sporocyst after $24 \mathrm{~h}$ sporulation, becoming ellipsoidal (ca $8 \times 4 \mu \mathrm{m}$ ) and consisting of scattered particles after $48 \mathrm{~h}$ of sporulation in tap water.

In histological preparations the earliest developmental stages of Goussia balatonica were meronts which developed in a given segment of the foregut, and extended into ca 3 to 5 intestinal folds (Fig. 7). In that segment of the gut almost all epithelial cells were infected and each contained a meront which was located in the cytoplasm apical to the nucleus. Meronts measured $17 \times 8 \times 8 u \mathrm{~m}$ and contained 32 bananashaped merozoites.

Figs. 6 to 9. Goussia spp. ( $\mathrm{H} \&$ E). Fig. 6. Blicca bjoerkna. Intestinal segment exhibiting mixed infection by nodular stages of $G$. balatonica and epicellular developmental stages of G. pannonica. mi: microgamont; ma: macrogamont; e: epicellular stages; ( $\times$ 500). Fig. 7. Goussia balatonica. Meronts infecting gut epithelium in single nodule. Almost all epithelial cells are infected by meronts containing 32 merozoites; $(\times 300)$. Fig. $8, G$, balatonica. Round trophozoites 3 to $8 \mu$ m diam. developing, probably, into gamonts are located in the epithelial cell cytoplasm in a given segment of the gut $(\times 200)$. Fig. 9. G. balatonica. Dark staining microgamonts (mi) located among macrogamonts in affected part of gut epithelium. Young microgamonts contain dot-shaped while the more developed ones have comma-shaped microgametes; $(\times 500)$ 

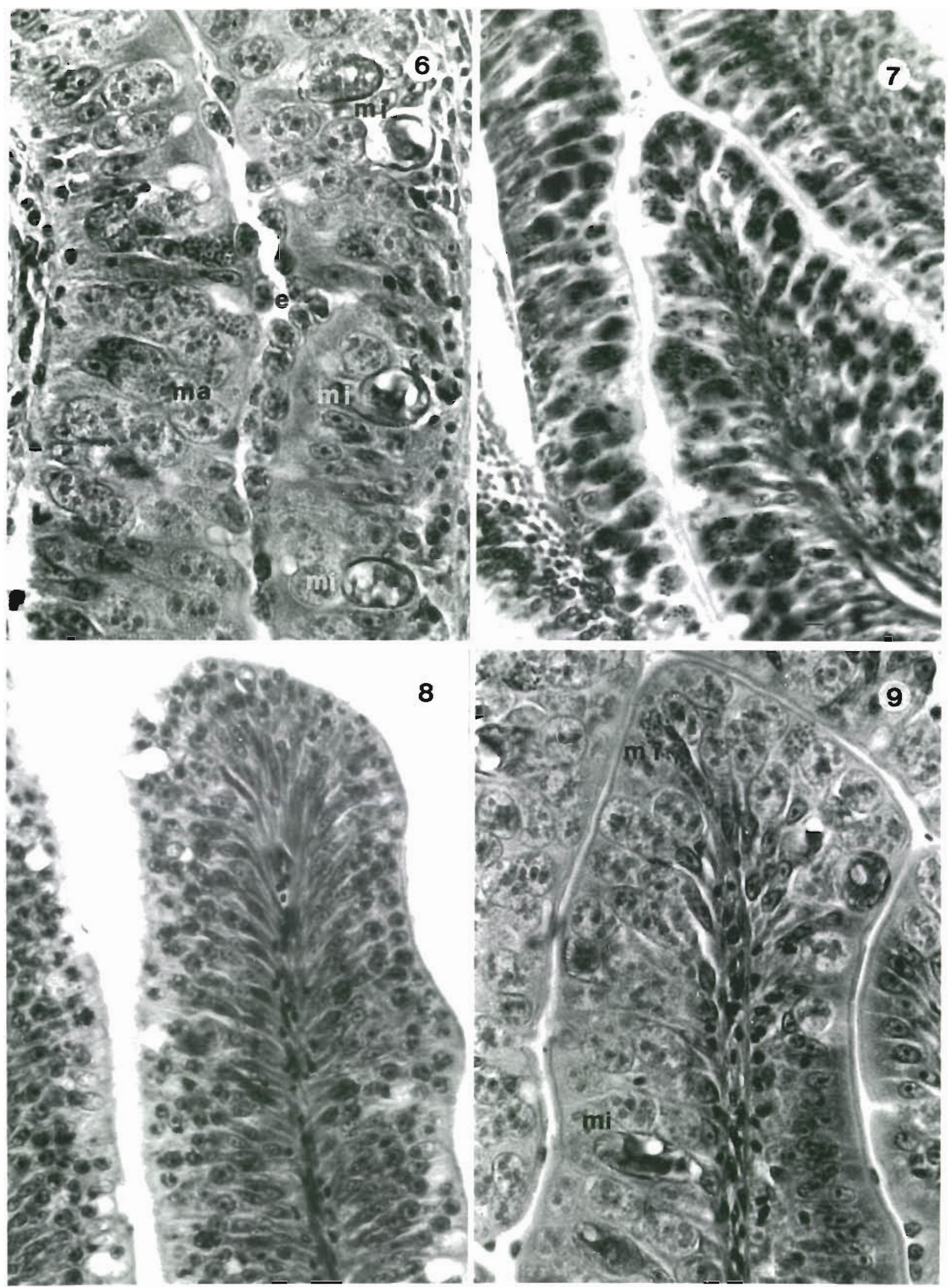
Gamogonic stages were also limited to a given segment of the gut; besides the foregut, they were also observed in the midgut and hindgut. Round trophozoites 3 to 8 um diam. (Fig. 8) and gamonts were located in the epithelial cell cytoplasm apical to the nucleus and pushed the nucleus to the basement membrane. Macrogamonts developing in the cell (Fig. 9) were mostly elliptical and $17-19 \times 12-14$ um. A central nucleus and some basophilic protein granules were seen in their foamy cytoplasm. Young microgamonts (Fig. 9) stained much darker. During development, the abundant chromatin of microgametes first appeared as small dots, then as elongated 'commas' within the ellip tical microgamonts which measured 19-25 × 13-14 $\mu \mathrm{m}$

Other species resembling Goussia balatonica differ from it in the following respects: $(\dot{y}$. subepitheilails has less elongated oocysts (Fig. 4); $G$. pigra has more elongated sporocysts; $G$. schulmani has a coarsely granulated sporocyst residuum; and $G$. molnari has sporozoits with reflexed ends. Besides these characteristics G. subepithelialis, G. schulmani, and G. molnari have endogenous sporogony.

Goussia pannonica n. sp., found in white bream, Blicca bjoerkna, of Lake Balaton and the River Danube, infects the epicellular layer of epithelial cells, mainly in the first half of the gut.

Ellipsoidal oocysts (Fig. 10), 15 (14-16) um long and

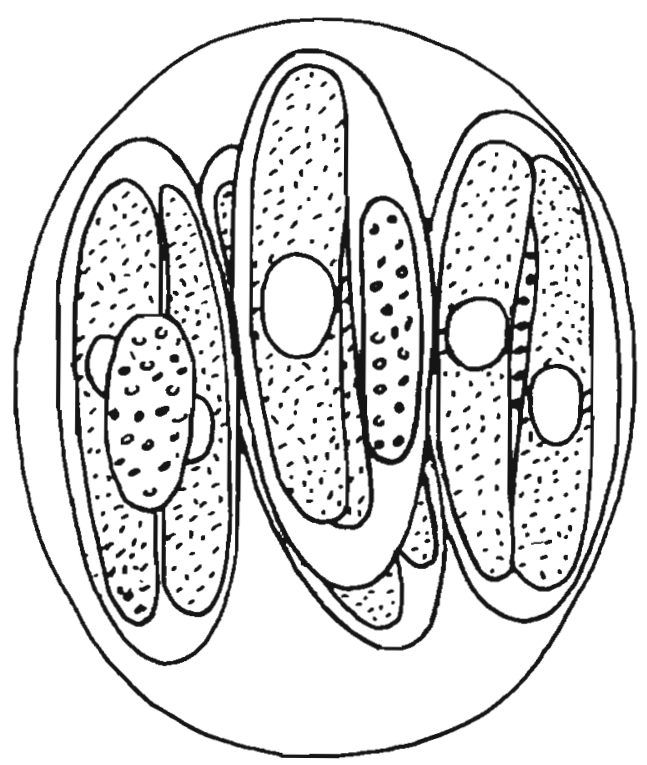

$10 \mu \mathrm{m}$

Fig. 10. Goussia pannonica. Oocyst (these are smaller and more elongated than these of G. balatonica, Fig. 5)
$12.2(11-14)$ um wide, have a thin, smooth and colourless wall. Oocyst residuum, polar granule and micropyle are absent. The oocysts leave the fish unsporulated, are (Fig. 1) compact, ellipsoidal and measure $12.9 \times 8.6(12.5-13.6 \times 8.3-9.8) \mu \mathrm{m}$. When kept in tap water at $22^{\circ} \mathrm{C}$ complete sporulation occurs within $48 \mathrm{~h}$. Merogonic and gamogonic stages were also studied histologically.

Sporocysts are elongated ellipsoidal, $11.8(11-13) \mathrm{um}$ long and $4(3-4.5) \mu \mathrm{m}$ wide, are generally longitudinally arranged in the oocyst, have thin walls and are composed of 2 equal valves. Each sporocyst contains 2 banana-shaped sporozoites with large refractile nuclei 9.5 (8.5-10.5) $\mu \mathrm{m}$ long and $2.1(2-2.5) \mu \mathrm{m}$ wide. The residuum is finely granulated and fills the sporocyst after $24 \mathrm{~h}$ sporuidiun sucil that after $48 \mathrm{~h}$ in, sporocysts are ellipsoidal, ca $8 \times 4 \mu \mathrm{m}$; and after $72 \mathrm{~h}$ consists of scattered particles.

Developmental stages of Goussia pannonica were demonstrable in all segments of the gut and were always located epicellularly (intracellularly but extracytoplasmally) (Fig. 11). The earliest stages were round meronts 5.5 to $6 \mu \mathrm{m}$ diam., containing 8 merozoites, which were usually demonstrable among developing gamonts (Fig. 12). Mature macrogamonts and microgamonts (Fig. 11) were ellipsoidal and $10-12 \times 8-9 \mu \mathrm{m}$ in size. In the pale cytoplasm of the macrogamonts, besides the nucleus, a few dark-staining protein granules were seen. Depending on their stage of maturity, microgamonts contained dot- or comma-shaped microgametes rich in chromatin.

This species resembles Goussia balatonica but differs from it in its smaller size, its specific epicellular location in the gut and the number of merozoites in meronts

\section{DISCUSSION}

The results indicate that, besides Goussia subepithelialis infection of common carp (Schäperclaus 1943, Pellérdy \& Molnar 1968, Marincek 1973) and coccidiosis reported by Molnár (1982) from tench, nodular coccidiosis frequently occurs in other cyprinid fishes. These studies also prove that in these fishes the nodular form is often accompanied by epicellular, diffuse coccidiosis. Both types of coccidiosis are characterized by a strictly seasonal, annual developmental cycle. Under the climatic conditions prevailing in Hungary merogony occurs until March and gamogony takes place in April. Oocysts leave the fish unsporulated before the end of April. Infection is not demonstrable in other periods of the year Rapid regeneration of the gut epithelium is also typical; as a result, even intensive infections disappear without a trace.

The fact that nodular and epicellular coccidiosis of 


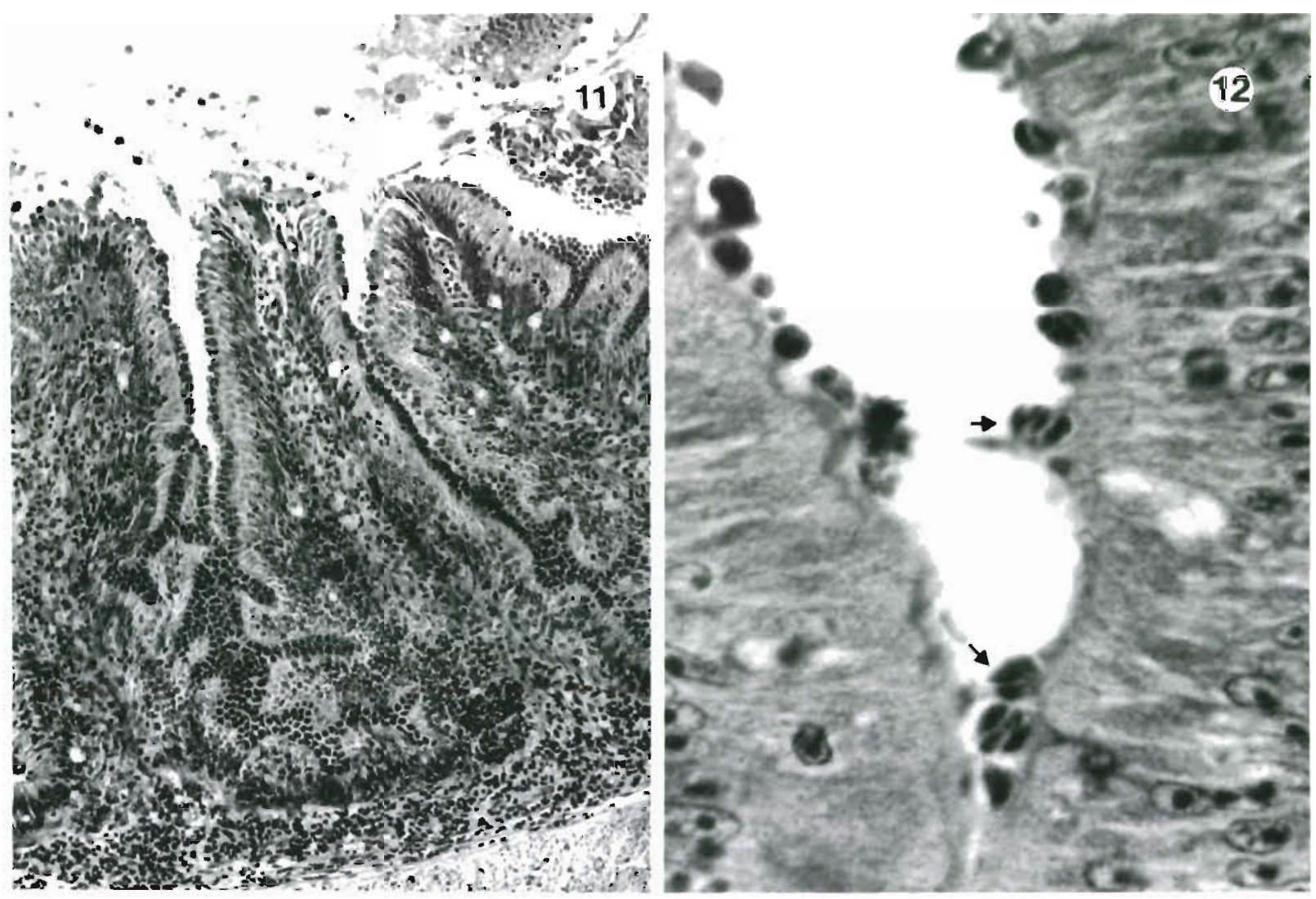

Figs. 11 and 12. Goussia pannonica (H \& E). Fig. 11. Developmental stages, covering surface of intestinal epithelial cells in large numbers; $(\times 100)$. Fig. 12. Meronts (arrows) developing epicellularly in intestinal epithelial cells; $(\times 800)$

cyprinids have so far largely escaped the attention of specialists, can be explained by several factors. These parasites can be demonstrated only in the early spring months when the collection of host fish is difficult. Specialists dealing with fish coccidia do not routinely perform histological examinations. While looking for sporulated oocysts they may overlook unsporulated oocysts which can easily be mistaken for food organisms.

On the basis of significant differences in oocyst size and location, and despite the morphological resemblance, nodular coccidiosis and epicellular coccidiosis observed in a given cyprinid species are unquestionably caused by 2 distinct species. In spite of this fact, consistent simultaneous occurrence of the 2 types might suggest that the nodular and epicellular forms are 2 different manifestations caused by the same species but altered by the host response. This conclusion was drawn by Landsberg \& Paperna (1987) who suggested that Eimeria vanasi, a species described by them, had 2 forms differing in size and location. This supposition is contradicted in the present study, by the observation that oocysts of intermediate size do not occur even if both types are present simultaneously, and that oocysts always fall into 2 distinct categories. That the 2 species are identical is practically excluded by the fact that the gamogonic stages of Goussia balatonica develop from a meront containing 32 merozoites, whereas in the meronts of $G$. pannonica only 8 merozoites are formed.

The developmental cycle of Goussia balatonica closely resembles that reported for $G$. subepithelialis. In $G$. balatonica the late stage of merogony, presumably corresponding to the 3rd merogonic generation, occurs in early spring, similar to the cycle of $G$. subepithelialis as reported by Marincek (1973). This stage is followed by gamogony lasting for, at most, 2 mo. According to Marincek (1973), infection of common carp with $G$. subepithelialis takes place in summer, and within ca 2 mo, 2 merogonic generations develop in the gut epithelium. However, a hibernation period is required for the $3 \mathrm{rd}$ merogonic stage. This fact would explain the annual developmental cycle.

The present study gives no information on the mode of infection by Goussia balatonica and G. pannonica. Marincek (1973) successfully infected common carp with G. subepithelialis directly. Similarly, Paterson \& Desser (1982) could produce infection in fathead min- 
now by feeding oocysts of $G$. iroquoina. On the other hand, to produce infection with Calyptospora (Eimeria) funduli in killifish. Fournie \& Overstreet (1983) needed intermediate hosts.

While surveying coccidial infections in the present study a basic question emerged: what kind of host specificity do these morphologically similar coccidia, characterized by very thin oocyst and sporocyst walls and a sporocyst composed of 2 valves, have? Are there, within the nodular and epicellular types of coccidiosis, morphologically similar but strictly specific Goussia species, each of which can colonize a single host, or are all cyprinid fishes infected by the same, morphologically variable species?

Considering the assumed specificity of coccidia and the phylogenetic distance of the hosts, most probably both nodular and epicellular coccidia are able to establish themselves in only a few closely related species, similarly to the spleen-parasitic Goussia mechnikowi, which can parasitize only Gobio spp., or to the intestinal parasite $G$. sinensis, which exclusively parasitizes Hypophthalmichthys spp. Assuming a similar specificity, it is not probable that $G$. balatonica is identical to $G$. subepithelialis reported from the genus Cyprinus, or to G. schulmani reported from the genus Leuciscus. At the same time, it cannot be ruled out that Goussia II and Goussia III, species demonstrated in the closely related Rutilus rutilus and Leu- ciscus cephalus, respectively, should be classified as G. schulmani.

Despite the fact that, apart from Goussia subepithelialis and nodular coccidia reported from tench by Molnár (1982), the literature does not contain factual data on the occurrence of nodular coccidiosis, it is highly probable that species listed in Table 3 were described from unrecognized cases of nodular coccidiosis. Besides the morphological resemblance, this was suggested by Hoffman (1965) and Jastrzebski (1984), both of whom observed oocyst shedding in the early spring months

To determine whether Goussia balatonica represents a distinct species, it should be compared to $G$. subepithelialis of common carp as an archetype. There are only slight differences between the oocysts of these 2 parasite species (Figs. 3 and 4). In the mechanism of oocyst excretion, however, important differences are demonstrable. Oocysts of $G$. balatonica leave the fish unsporulated in April (similarly to that reported by Molnár 1982 for coccidiosis of tench). On the other hand, oocysts of $G$. subepithelialis reach the deep layers of the epithelium and leave the fish in the sporulated state in May. This opinion, generally accepted in the literature, is somewhat contradicted by the observation of Marincek (1973), i. e. that some oocysts of $G$. subepithelialis also leave the fish unsporulated in April, suggesting that differences in the oocyst excretion

Table 3. Goussia spp. G. balatonica- and G. pannonica-type coccidia reported from cyprinid fishes. Shapes: (r) round $(e)$ ellipticali (o) ovoid

\begin{tabular}{|c|c|c|c|c|c|c|c|}
\hline \multirow[t]{2}{*}{ Coccidian species } & \multirow[t]{2}{*}{ Host } & \multicolumn{3}{|c|}{ Oocyst } & \multicolumn{3}{|c|}{ Sporocyst } \\
\hline & & Shape & Length & Width & Shape & Length & Width \\
\hline \multicolumn{8}{|c|}{ Eimeria (Goussia) subepithelialis } \\
\hline \multicolumn{8}{|c|}{ Moroff \& Fiebiger, 1905} \\
\hline Marincek (1973) & Common carp & $\mathrm{r}$ & $20-21$ & - & e & $9.3-12.5$ & $4.6-6.2$ \\
\hline Schäperclaus (1943) & & r & $18-21$ & - & e & 15 & 8 \\
\hline Pellérdy \& Molnár (1968) & Common carp & r & $18-22$ & - & e & $15-16$ & 8 \\
\hline \multicolumn{8}{|l|}{ Eimeria pigra } \\
\hline Leger \& Bory, 1932 & Rudd & e & $17-19$ & 14 & e & 15 & $4.5-5$ \\
\hline \multicolumn{8}{|l|}{ Eimeria schulmani } \\
\hline Kulemina, 1969 & Orfe & r & $189-22$ & - & e & $15-17$ & $6.9-7.8$ \\
\hline \multicolumn{8}{|l|}{ Eimeria schulmani } \\
\hline \multicolumn{8}{|l|}{ Kulemina, 1969} \\
\hline Jastrzebski (1984) & Chub & e & $15.9-19.7$ & $13-15.4$ & e & $11.1-15.5$ & $4.8-7.1$ \\
\hline \multicolumn{8}{|l|}{ Eimeria molnari } \\
\hline Jastrzebski, 1984 & Gudgeon & e & $18.6-20.5$ & $11.4-13.8$ & e & $10.2-12.5$ & $4.9-6.1$ \\
\hline \multicolumn{8}{|l|}{ Eimeria carassiusaurati } \\
\hline Romero-Rodriguez, 1978 & Goldfish & $\mathrm{r}$ & $15.2-13.3$ & - & e & 13.6 & 5.8 \\
\hline \multicolumn{8}{|l|}{ Eimeria aurati } \\
\hline Hoffman, 1965 & Goldfish & e & $16-24$ & $14-17$ & e & $11-13$ & $6.5-8$ \\
\hline \multicolumn{8}{|l|}{ Eimeria carassii } \\
\hline Yakimoff \& Gouseff 1935 & Crucian carp & r & $19-24$ & - & e & - & - \\
\hline \multicolumn{8}{|l|}{ Eimeria nicollei } \\
\hline Yakimoff \& Gouseff, 1935 & Crucian carp & o & $22-32$ & $13-20$ & e & - & - \\
\hline
\end{tabular}


mechanism reflect the characteristics of the host reaction rather than the properties of coccidia. Species important in respect of differentiation, e.g. G. schulmain, G. molnari, and G. carassiusaurati, also excrete sporulated oocysts, and only the oocysts of $G$. aurati and $G$. pigra are known to leave the fish unsporulated

Until quite recently, Eimeria anguillae infection of eel and Goussia pigra infection of rudd were the exclusive examples of epicellular coccidiosis. Recent data (Molnár 1986, Daoudi et al. 1987, Landsberg \& Paperna 1987, Kent et al. 1988, Molnár \& Rohde 1988a) indicate that this type of coccidiosis occurs frequently and in different fish species. Important data can be found in the book of Kocylowski \& Myaczynski (1963) who, in connection with $G$. pigra infection of rudd, mention that similar eimerians of epicellular location are frequently demonstrable from the gut of other fishes, too. Though light-microscopic examination alone does not have probative value, by analogy it is beyond doubt that the 'epicellular' developmental stages of G. pannonica n. sp. occupy a similar intracellular but extracytoplasmal position as was proved ultrastructurally by Molnár \& Baska (1986) for Epieimeria anguillae.

The species Goussia pigra occupies a peculiar place in this respect. This parasite was described by Leger \& Bory (1932) from Scardinius erythrophthalmus. At the same time, its oocyst measurements are closer to those of nodular coccidia. Though I have studied only the smaller, sporulated oocyst forms from rudd, I assume that Leger \& Bory (1932) must have observed a mixed infection usual in cyprinids, and they must have described the species on the basis of oocysts derived from the nodule and histologically demonstrated only the epicellular forms.

Numerous attempts have been made at classifying the genus Eimeria Schneider, 1875, a genus comprising an extremely large number of species. Among the eimerians of fishes, on the basis of oocyst morphology, Labbé (1896) created the genera Goussia and Crystallospora, whereas Overstreet et al. (1984) established the genus Calyptospora. On the basis of intracellular location Dykova \& Lom (1981) suggested the genus Epieimeria and Daoudi (1987) recommended the genera Nucleoeimeria and Nucleogoussia. The species G. balatonica and G. pannonica, described in this work, are typical members of the genus Goussia as shown by their sporocysts composed of 2 valves joined by a suture. However, by its location within the cell G. pannonica could be assigned to the genus Epieimeria, or to the still non-existent genus Epigoussia. In my opinion, location within the cell cannot be accepted as a generic character, as the location of most of the presently known species is unknown. Working from this principle, such still unelucidated factors as e.g. development with or without an intermediate host or development by a yearly cycle or continuously, could also serve as a basis for taxonomic classification.

\section{LITERATURE CITED}

Daoudi, F. (1987). Coccidies et coccidioses de poissons mediterraneens: systématique, ultrastructure et biologie. Doctoral thesis, Montpellier

Daoudi, F., Radujkovic, B., Marques, A., Bouix, G. (1987). Nouvelles espèces de Coccidies (Apicomplexa, Eimeriidae) des genres Eimeria Schneider, 1875, et Epieimeria Dykova et Lom, 1981, parasites de poissons marins de la baie de Kotor (Yugoslavie). Bull. Mus. natn. Hist. nat. Paris (4 Sér.) A 9: 321-332

Dykova, I., Lom, J. (1981). Fish coccidia: critical notes on life cycles, classification and pathogenicity. J. Fish Dis. 4: $487-505$

Fournie, J. W., Overstreet, R. M. (1983). True intermediate hosts for Eimeria funduli (Apicomplexa) from estuarine fishes. J. Protozool 30: 672-675

Hoffman, G. L. (1965). Eimeria aurati n. sp. (Protozoa: Eimeriidae) from goldfish (Carassius auratus) in North America. J. Protozool. 12: 273-275

Jastrzebski, M. (1984). Coccidiofauna of cultured and feral fishes in fish farms. Wiad. parazyt. 30: 141-163

Jastrzebski, M., Pastuszko, J., Kurska, E., Badowska, M. (1988). Kokcydia ciernika - Gasterosteus aculeatus (L.). Wiad. parazyt. 34: 55-63 (in Polish)

Kent, M. L., Fournie, J. W., Snodgrass, R. E., Elston, R. A. (1988). Goussia girellae n. sp. (Apicomplexa: Eimeriorina) in the opaleye, Girella nigricans. J. Protozool. 35: 287-290

Kocylowski, B., Myaczynski, T (1963). Fish diseases. Publ. House Mezögazdasági, Budapest (in Hungarian)

Labbé, A. (1896). Recherches zoologiques, cytologiques et biologiques sur les Coccidies. Archs Zool exp. gén. 4: $517-654$

Landsberg, J. H., Paperna, I. (1987). Intestinal infections by Eimeria (s. l) vanasi n. sp. (Eimeriidae, Apicomplexa, Protozoa) in cichlid fish. Ann. Parasitol. Hum. Comp. 62: 283-293

Leger, M., Bory, T (1932). Eimeria pigra n. sp. nouvelle Coccidie juxtaepitheliale, parasite du Gardon rouge. C. r hebd. Séanc. Acad. Sci., Paris 194: 1710-1712

Lom, J., Dyková, I. (1982). Some marine fish coccidia of the genera Eimeria Schneider, Epieimeria Dyková et Lom and Goussia Labbé. J. Fish Dis. 5: 309-321

Marincek, M. (1973). Développement d'Eimeria subepithelialis (Sporozoa, Coccidia) - parasite de la carpe Acta protozool. 12: 195-215

Molnár, K. (1982). Nodular coccidiosis in the gut of the tench, Tinca tinca L. J. Fish Dis. 5: 461-470

Molnár, K. (1984). Some pecularities of oocyst rejection of fish coccidia. Symp. Biol. Hung. 23: 87-97

Molnár, K. (1986). Occurrence of two new Goussia species in the intestine of sterlet (Acipenser ruthenus). Acta vet. hung. 34: 169-174

Molnár, K., Baska, F. (1986). Light and electron microscopic studies on Epieimeria anguillae (Leger et Hollande, 1922). a coccidium parasitizing the European eel, Anguilla anguilla L. J. Fish Dis. 9: 99-110

Molnár, K., Rohde, K. (1988a). New coccidians from freshwater fishes of Australia. J. Fish Dis. 11: 161-169 
Molnár, K., Rohde, K. (1988b). Seven new coccidian species from marine fishes in Australia. Syst. Parasitol. 11: 19-29

Obikezie, A. I. (1986). Goussia ethmalotis n. sp. (Apicomplexa, Sporozoa), a coccidian parasite of the West African Shad, Ethmalosa fimbriata Bowditch, 1925 (Pisces: Clupeidae). Z. ParasitKde 72: 827-829

Overstreet, R. M., Hawkins, W. E., Fournie, J. W. (1984). The coccidian genus Calyptospora n. g. and family Calyptosporidae n. fam. (Apicomplexa) with members infecting primarily fishes. J. Protozool. 31: 332-339

Paterson, W. B., Desser, S. S. (1982). The biology of two

Responsible Subject Editor: Professor W. Körting, Hannover, F.R. Germany
Eimeria species (Protista: Apicomplexa) in therr mutual fish hosts in Ontario. Can. J. Zool. 60: 764-775

Pellérdy, L., Molnár, K. (1968). Known and unknown eimerian parasites of fishes in Hungary. Folia Parasitol. (Prague) 15. $97-105$

Schäperclaus, W. (1943). Die Darmcoccidiosen, insbesondere die Knötchencoccudiose des Karpfens. Z. Fisch. 41: 283-295

Upton, S. J., Reduker, D. W., Current, W. L., Duszynski, D. W (1984). Taxonomy of North American fish: Eimeridae NOAA tech. Rep. NMFS US Dep. Commerce 11 1-18

Manuscript first received: January 31, 1989

Revised version accepted: June 30, 1989 